\title{
A single-fibre electromyography study of neuromuscular transmission in patients with cluster headache
}

\section{Elektromiografia pojedynczego włókna u chorych na klasterowy ból głowy}

\author{
Izabela Domitrz', Małgorzata Gaweł', Wojciech Domitrz², Anna Kostera-Pruszzzyk', Hubert Kwieciński' \\ 'Department of Neurology, Medical University of Warsaw, Poland \\ 2Faculty of Mathematics and Information Science, Warsaw University of Technology, Warsaw, Poland
}

Neurologia i Neurochirurgia Polska 2012; 46, 2: 140-144

DOI: 10.5114/ninp.2012.28256

\begin{abstract}
Background and purpose: Mutations of CACNA1A, which encodes a neuronal $\mathrm{P} / \mathrm{Q} \mathrm{Ca}{ }^{2+}$ channel, are present in patients with familial hemiplegic migraine, and possibly in other types of migraine as well. This calcium channel is also involved in neuromuscular transmission. In our previous study we confirmed that the single-fibre electromyography (SFEMG) method can demonstrate a neuromuscular transmission deficit in migraine with aura. The aim of our present study was to estimate the neurotransmitter dysfunction in cluster headache and to compare the results between patients with cluster headache and those with migraine with aura.

Material and methods: We selected 6 patients with cluster headache and 6 patients with migraine with typical aura. SFEMG of the voluntarily activated extensor digitorum communis muscle was performed.

Results: The SFEMG results were in the normal range in the cluster headache group and in the healthy controls. Slight neuromuscular transmission disturbances were present in patients with migraine with aura.

Conclusions: The abnormal neuromuscular transmission detectable by SFEMG may reflect a genetically determined dysfunction of the $\mathrm{P} / \mathrm{Q} \mathrm{Ca}^{2+}$ channels in a group of migraineurs with aura. Conversely, absence of neuromuscular abnormalities in cluster headache patients could be explained by different aetiology not resulting in channelopathy. Single-fibre
\end{abstract}

\section{Streszczenie}

Wstęp i cel pracy: U chorych na migrenę rodzinną połowiczoporaźną, a także $\mathrm{z}$ innymi postaciami migreny z aurą stwierdzono mutację w genie CACNA1A dla kanału wapniowego $\mathrm{P} / \mathrm{Q}$. Z uszkodzeniem tego kanału wapniowego związane są zaburzenia przewodzenia nerwowo-mięśniowego. We wcześniejszej pracy autorzy opisali badanie za pomocą elektromiografii pojedynczego włókna (SFEMG) zaburzeń przewodzenia nerwowo-mięśniowego u osób z migreną, stwierdzając ich obecność u części pacjentów z migreną $z$ aurą. Celem niniejszego badania jest odpowiedź na pytanie, czy u pacjentów z klasterowym bólem głowy występują podobne zaburzenia, i porównanie wyników otrzymanych u osób z klasterowym bólem głowy z wynikami pacjentów z migreną $\mathrm{z}$ aurą.

Materiał i metody: Elektromiografię pojedynczego włókna wykonaną z mięśnia zginacza długiego palców przeprowadzono u 6 pacjentów z klasterowym bólem głowy i zestawiono ją z wynikami 6 chorych na migrenę $\mathrm{z}$ aurą.

Wyniki: Wyniki SFEMG w grupie chorych na klasterowy ból głowy mieściły się w prawidłowych granicach, podobnie jak w grupie kontrolnej zdrowych osób. W grupie pacjentów $\mathrm{z}$ migreną $\mathrm{z}$ aurą stwierdzono łagodne zaburzenia transmisji nerwowo-mięśniowej.

Wnioski: Nieprawidłowe wyniki SFEMG mogą wskazywać na genetycznie uwarunkowaną dysfunkcję kanału wapniowego

Correspondence address: Izabela Domitrz, Department of Neurology, Medical University, 1A Banacha Street, 02-097 Warsaw, Poland, phone: +482259928 57,fax: +482259918 57, e-mail: izabela.domitrz@wum.edu.pl

Received: 24.09.2011; accepted: 15.12.2011 
electromyography could be a helpful tool in clinically questionable cases in differentiating between cluster headache and migraine with aura.

Key words: cluster headache, migraine with aura, $\mathrm{P} / \mathrm{Q} \mathrm{Ca}{ }^{2+}$ channels, single-fibre electromyography, neuromuscular transmission.

\section{Introduction}

In our previous study, we demonstrated that singlefibre electromyography (SFEMG) can reveal mild neuromuscular transmission deficit in patients with migraine with aura [1]. Abnormal neuromuscular transmission in patients with cluster headache was also reported [2,3].

Although the patients with migraine or cluster headache do not have clinical symptoms of neuromuscular transmission defect, SFEMG abnormalities may suggest a dysfunction of $\mathrm{P} / \mathrm{Q} \mathrm{Ca}{ }^{2+}$ channels. Mutations of the CACNA1A gene (chromosome 19p13) were first described in patients with episodic ataxia type 2 and spinocerebellar ataxia type $6[4]$. In addition, it has also been demonstrated that $C A C N A 1 A$ mutations are present in about $50 \%$ of families with hemiplegic migraine [4-6]. In a single report by Baslo et al. [7] subclinical neuronal muscular transmission (NMT) abnormality was found in sporadic hemiplegic migraine and basilar type migraine patients.

We aimed to look for subclinical impairment of NMT as a possible indicator of underlying ion channelopathy in cluster headache patients.

\section{Material and methods}

We studied a group of six patients with cluster headache, six patients with migraine with typical aura and six healthy age-matched controls.

Cluster headache and migraine with aura were diagnosed according to the International Headache Society criteria, $2^{\text {nd }}$ edition [8].

The cluster headache group consisted of 6 patients: 2 women and 4 men at a mean age of $43.5 \pm 8.7$ years. The migraine with aura group (IHS code 1.2.1) consisted of 6 women at a mean age of $41.5 \pm 12.6$ years. All patients with migraine with aura had attacks of migraine with typical aura. None of the migraine with $\mathrm{w}$ grupie chorych na migrenę $\mathrm{z}$ aurą w przeciwieństwie do chorych na klasterowy ból głowy, u których najprawdopodobniej etiologia choroby ma inne podłoże. Badanie SFEMG może być badaniem pomocniczym w różnicowaniu niepewnych przypadków klasterowego bólu głowy imitujących migrenowy ból głowy.

Słowa kluczowe: klasterowy ból głowy, migrena z aurą, kanały wapniowe $\mathrm{P} / \mathrm{Q}$, zaburzenia transmisji nerwowo-mięśniowej, elektromiografia pojedynczego włókna.

aura or cluster headache patients suffered from other coexisting headaches or other disorders. The control group consisted of 6 healthy women (mean age of 42.5 \pm 9.7 years)

The study protocol was approved by the local ethics committee and the study was conducted with the informed consent of all subjects.

The SFEMG examination was conducted by an investigator blinded to the clinical diagnosis of the patient. Single-fibre electromyography of the voluntarily activated extensor digitorum communis muscle was conducted as described by Stalberg et al. [9,10], using a Keypoint electromyograph (Medtronic, Skovlunde, Denmark). In all tested subjects, 20 potential pairs were collected, and the mean consecutive difference (MCD) - jitter - value was subsequently calculated for each pair. The MCD is the mean of the differences between the intervals between consecutive potential pairs, calculated by the software, and is a standard parameter for assessment of NMT, reflecting the safety factor of the neuromuscular junction [11]. The mean MCD value and the number of potential pairs with an MCD exceeding $55 \mu$ s or blocking were noted [12].

The results were compared with our laboratory reference values and considered abnormal when the mean MCD value exceeded $33.8 \mu$ s, or more than $10 \%$ of pairs had an MCD value above $55 \mu$ s with or without blocking.

All patients were examined interictally, at least three weeks after the last episode of headache. The patients were not receiving any drugs for a period of 3 weeks before the SFEMG examination. Because cluster headache is presumed to activate the trigemino-vascular system, we additionally tested the blink reflex in three women with cluster headache (age range 39-69; mean 50.6). The blink reflex was elicited with electrical stimulation of the left and right supraorbital nerve with an early, ipsilateral R1 and a late, bilateral R2 response. 
Table 1. Results of single-fibre electromyography (SFEMG) studies in the study groups

\begin{tabular}{|lccc|}
\hline Group & Cluster headache $(\boldsymbol{n}=\mathbf{6})$ & Migraine with aura $(\boldsymbol{n}=\mathbf{6})$ & Control group $(\boldsymbol{n}=\mathbf{6})$ \\
\hline MCD $[\mu \mathrm{s}]$, mean $\pm \mathrm{SD}($ range) & $30 \pm 5.8(24-40)$ & $32 \pm 2.9(28-36)$ & $27 \pm 2.2(23-29)$ \\
\hline Range of MCD of individual potential pairs & $11-69$ & $15-64$ & $12-45$ \\
\hline No. of abnormal SFEMG tests & $1 / 6(16.6 \%)$ & $5 / 6(83 \%)$ & $0 / 6(0 \%)$ \\
\hline
\end{tabular}

$S D$ - standard deviation, $M C D$ - mean of differences between intervals between consecutive potential pairs

Electrical stimulation of supraorbital nerves was performed with a peripheral nerve stimulator and silver/silver chloride disc surface electrodes.

The results were expressed as means and standard deviations for quantitative variables and as proportions for binary data. Means in each group were compared by one-way analysis of variance. Significance of difference between pairs of groups and the correlation between values were checked by $t$-tests. Statistical calculations were carried out using Statistica software with $p<0.05$ taken as a cut-off value.

\section{Results}

The SFEMG results are presented in Table 1 and Fig. 1. The results (mean MCD) were within the normal range in the patients with cluster headache and in the control group. Only in one cluster headache case $(1 / 6,16.6 \%)$ did the examination reveal borderline dysfunction of neurotransmission. There was no significant difference between the results of jitter values in patients with cluster headache compared to controls. Mild NMT impairment was found in some of the patients with migraine with aura. All patients showing NMT

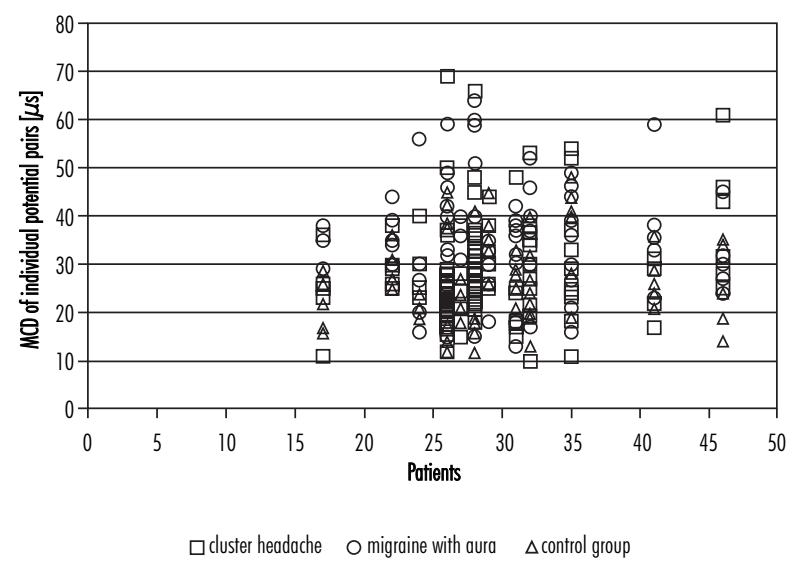

Fig. 1. Results of mean of differences between intervals between individual consecutive potential pairs (MCD) in patients with cluster headache, migraine with aura and control group impairment had only slight SFEMG abnormalities, with mean MCD values just above the upper limit of normal. Pairs of potentials with an MCD above $55 \mu \mathrm{s}$ were recorded in patients with migraine with aura, but no blocking was observed. The individual MCD values were shifted towards the upper limit of normal for a single potential pair in each case. Although there was a significant difference of the mean MCD between the control group and patients with migraine with aura $(p=0.003)$, no such difference was demonstrated between the cluster headache group and healthy controls $(p=0.24)$ or between the group of patients with cluster headache and the migraine with aura group $(p=0.38)$. There was no correlation between age and onset of disease and jitter results in study groups.

Blink reflex examination revealed normal latencies and amplitudes of R1 and R2 responses in all three patients with cluster headache.

\section{Discussion}

Our study did not reveal subclinical impairment of NMT in cluster headache patients in contrast to mild dysfunction in a subgroup of patients with migraine with aura, as observed previously by other authors [13-15]. To date only a small number of studies have analysed SFEMG in cluster headaches. Ertas et al. [3] suggested that episodic cluster headache might share the same abnormality of neuromuscular transmission observed in migraine. They found subclinical abnormality in jitter results in 3 of 6 patients with cluster headache [3]. In a subsequent study, Coban et al. [2] demonstrated that the subclinical NMT abnormality shown by SFEMG was more common in cluster headache $(21.6 \%)$ than in MA (11.6\%).

In migraines with aura, NMT dysfunction could be explained by underlying genetic factors inducing a $\mathrm{Ca}$ channelopathy which accounts for both the headache phenotype and transmission abnormalities, but there is no such suggestion in cluster headache. The aetiology 
of cluster headache is currently unknown. The first hypothesis was based on the neurovascular theory. In cluster headache, activation of the trigemino-vascular system is present, but it is not established whether this is a cause or consequence of cluster headache. The parasympathetic activation is thought to be mediated by a trigemino-autonomic reflex in the brainstem circuitry via the seventh cranial nerve. However, we examined the motor part of the trigeminal-facial circuitry by blinkreflex interictally and we did not reveal any abnormalities in cluster headache patients. Raudino tested the electrically elicited blink reflex during a symptomatic period in patients with cluster headache. In nearly all cases (11/12), the amplitude of the contralateral R2 response on the symptomatic side was significantly lower [16]. In our 3 patients with cluster headache, blink reflex did not reveal any differences between the symptomatic and asymptomatic side.

On the other hand, the activation of the posterior hypothalamus during attacks probably plays a role in cluster headache. Also, more studies have recently been done on polymorphism of the HCRTR2 gene (hypocretin receptor 2), which could be a susceptibility gene in cluster headache. Hypocretin is secreted by the hypothalamus activated in cluster headache [17].

The absence of neurotransmitter dysfunction in cluster headache could be explained by a different mechanism and lack of pathology of ion channels identified in migraine with aura.

The SFEMG abnormalities present in our migraineurs were mild. They were manifested as a shift of individual MCD values towards the upper limit of normal. Although in a few potential pairs the MCD values exceeded $55 \mu$ s, there was no blocking. Such findings could be interpreted as a mild, yet generalized reduction in the safety factor of the neuromuscular junction. Neuromuscular transmission abnormalities were reported by Ambrosini et al. [13], who studied NMT in patients with migraine with stimulated SFEMG, observing prolonged jitter and blocking. Recently, three patients were described with episodic ataxia type 2, in whom the mean MCD values fell between 40 and $59 \mu$ s, with maximal jitter values up to $214 \mu$ s, reaching the degree of abnormalities observed in myasthenic patients [18]. Therefore, the blinded setting of the SFEMG is recommended for studying migraine patients, as it decreases the possible observation bias. Single-fibre electromyography with voluntary activation, as employed in our study, excludes the risk of subthreshold stimulation as the cause of increased jitter or axonal blocking when the SFEMG is studied with axonal stimulation [19].

The fact that SFEMG abnormalities were limited to patients with migraine with aura may be an additional argument supporting the opinion that migraine and cluster headache are completely distinct disorders, and the cluster headache group may be heterogeneous group with different pathogenesis.

\section{Disclosure}

Authors report no conflict of interest.

\section{References}

1. Domitrz I., Kostera-Pruszczyk A, Kwieciński H. A single-fibre EMG study of neuromuscular transmission in migraine patients. Cephalalgia 2005; 25: 817-821.

2. Coban A., Baslo M.B., Baykan B., et al. Subclinical neuromuscular transmission abnormality detected by single-fibre EMG is more pronounced in cluster headache than in migraine with aura. Cephalalgia 2007; 27: 788-792.

3. Ertas M., Baslo B. Abnormal transmission in cluster headache. Headache 2003; 43: 616-620.

4. Ophoff R.A., Terwindt G.M., Vergouwe M.N., et al. Familial hemiplegic migraine and episodic ataxia type-2 are caused by mutations in the Ca2 + channel gene CACNL1A4. Cell 1996; 87: 543-552.

5. Joutel A., Bousser M., Biousse V., et al. A gene for familial hemiplegic migraine maps to chromosome 19. Nat Genet 1993; 5: 40-55.

6. Ophoff R.A., van Eijk R., Sandkuijl L.A., et al. Genetic heterogeneity of familial hemiplegic migraine. Genomics 1994; 22 : 21-26.

7. Baslo M.B., Coban A., Baykan B., et al. Investigation of neuromuscular transmission in some rare types of migraine. Cephalalgia 2007; 27: 1201-1205.

8. The International Classification of Headache Disorders. $2^{\text {nd }}$ ed. Cephalalgia 2004; 24: 24-36.

9. Stalberg E., Ekstedt J., Broman A. Neuromuscular transmission in myasthenia gravis studied with single fibre electromyography. J Neurol Neurosurg Psychiatry 1974; 37: 540-547.

10. Stalberg E., Ekstedt J., Broman A. The electromyographic jitter in normal human muscles. Electroencephalogr Clin Neurophysiol 1971; 31: 429-438.

11. Stalberg E., Schiller H.H., Schwartz M.S. Safety factor in single human motor end-plates studied in vivo with single fibre electromyography. J Neurol Neurosurg Psychiatry 1975; 38: 799-804.

12. Anonymous. Single fiber EMG reference values: a collaborative effort. Ad Hoc Committee of the AAEM Special Interest Group on Single Fiber EMG. Muscle Nerve 1992; 15: 151-161.

13. Ambrosini A., de Noordhout A.M., Schoenen J. Neuromuscular transmission in migraine patients with prolonged aura. Acta Neurol Belg 2001; 101: 166-170. 
14. Ambrosini A., de Noordhout A.M., Schoenen J. Neuromuscular transmission in migraine: a single-fiber EMG study in clinical subgroups. Neurology 2001; 56: 1038-1043.

15. Ambrosini A., de Noordhout A.M., Alagona G., et al. Impairment of neuromuscular transmission in a subgroup of migraine patients. Neurosci Lett 1999; 276: 201-203.

16. Raudino F. The blink reflex in cluster headache. Headache 1990; 30: $584-585$

17. Leroux E., Ducros A. Cluster headache. Orphanet J Rare Dis 2008; 3: 20

18. Jen J., Wan J., Graves M., et al. Loss-of-function EA2 mutations are associated with impaired neuromuscular transmission. Neurology 2001; 57: 1843-1848.

19. Terwindt G., Kors E., Haan J., et al. Mutation analysis of the CACNA1A calcium channel subunit gene in 27 patients with sporadic hemiplegic migraine. Arch Neurol 2002; 59: 1016-1018. 